\title{
Allocation of Decision Rights in Fruit and Vegetable Contracts in China
}

\author{
Yamei Hu and George Hendrikse
}

\begin{tabular}{|l|l|}
\hline \multicolumn{2}{|l|}{ ERIM REPORT SERIES RESEARCH IN MANAGEMENT } \\
\hline ERIM Report Series reference number & ERS-2007-077-ORG \\
\hline Publication & November 2007 \\
\hline Number of pages & 30 \\
\hline Persistent paper URL & \\
\hline Email address corresponding author & yhu@rsm.nl \\
\hline Address & Erasmus Research Institute of Management (ERIM) \\
& RSM Erasmus University / Erasmus School of Economics \\
& Erasmus Universiteit Rotterdam \\
& P.O.Box 1738 \\
& 3000 DR Rotterdam, The Netherlands \\
& Phone: $\quad+31104081182$ \\
& Fax: $\quad+31104089640$ \\
& Email: info@erim.eur.nl \\
& Internet: $\quad$ www.erim.eur.nl \\
\hline
\end{tabular}

Bibliographic data and classifications of all the ERIM reports are also available on the ERIM website: www.erim.eur.nl 


\section{ERASMUS RESEARCH INSTITUTE OF MANAGEMENT}

\section{REPORT SERIES}

\section{RESEARCH IN MANAGEMENT}

\begin{tabular}{|l|l|}
\hline \multicolumn{2}{|l|}{ ABSTRACT AND KEYWORDS } \\
\hline Abstract & $\begin{array}{l}\text { We empirically examine the determinants of the allocation of decision rights in the context of fruit } \\
\text { and vegetable contracting. The main conclusion is that under contract farming, many decision } \\
\text { rights are shifted from farmers to firms. Quality, reputation and specific investments by firms } \\
\text { positively influence the number of decision rights allocated to agri-business firms under contract } \\
\text { farming, while monopsony-oligopsony power and specific investments by farmers have no effect } \\
\text { on the allocation of decision rights. }\end{array}$ \\
\hline Free Keywords & $\begin{array}{l}\text { Decision rights, Contracts, China } \\
\text { Availability }\end{array}$ \\
$\begin{array}{l}\text { The ERIM Report Series is distributed through the following platforms: } \\
\text { Academic Repository at Erasmus University (DEAR), DEAR ERIM Series Portal } \\
\text { Social Science Research Network (SSRN), SSRN ERIM Series Webpage } \\
\text { Research Papers in Economics (REPEC), REPEC ERIM Series Webpage }\end{array}$ \\
\hline Classifications & $\begin{array}{l}\text { The electronic versions of the papers in the ERIM report Series contain bibliographic metadata } \\
\text { by the following classification systems: } \\
\text { Library of Congress Classification, (LCC) } \underline{\text { LCC Webpage }} \\
\text { Journal of Economic Literature, (JEL), JEL Webpage } \\
\text { ACM Computing Classification System CCS Webpage } \\
\text { Inspec Classification scheme (ICS), ICS Webpage }\end{array}$ \\
\hline
\end{tabular}




\title{
Allocation of Decision Rights in Fruit and Vegetable Contracts in China
}

\author{
Yamei Hu \\ George Hendrikse*
}

\begin{abstract}
We empirically examine the determinants of the allocation of decision rights in the context of fruit and vegetable contracting. The main conclusion is that under contract farming, many decision rights are shifted from farmers to firms. Quality, reputation and specific investments by firms positively influence the number of decision rights allocated to agri-business firms under contract farming, while monopsony-oligopsony power and specific investments by farmers have no effect on the allocation of decision rights.
\end{abstract}

\section{Keywords}

Decision rights, Contracts, China

\footnotetext{
* Yamei Hu and George Hendrikse are both at RSM Erasmus University, Office T08-56, PO Box 1738, 3000 DR Rotterdam, The Netherlands. Phone: 0031-10-4088660, Fax: 0031-10-4089015, Email: yhu@rsm.nl and ghendrikse@rsm.nl.
} 


\section{Introduction}

The use of contracts as a way of vertically organizing transactions is spreading in many agricultural sectors. Although cash markets are still important in coordinating supply and demands, however, different kinds of contractual arrangements gradually demonstrate their significance in providing links to all stakeholders. According to ERS/USDA (2006), contracts covered thirty nine percent of the value of U.S. agricultural production in 2003, up from thirty six percent in 2001 and twenty eight percent in 1991. Commodities such as tomatoes and broilers have been produced almost exclusively under contracts between processors and independent growers for decades in the United States (Vukina and Leegomonchai, 2004). Developing countries in Africa have adopted contract farming as one effective way of developing the local agricultural economy for decades (Litte and Watt, 1994). Developing countries are experiencing a rapid increase in contract farming recently, driven by globalization, trade liberalization and agricultural industrialization (Cook and Chaddad, 2000).

Within the broad category of contract farming, contractual arrangements vary a lot across different supply chains/relations between downstream firms and primary growers. First, some contracts assign the ownership of the commodity to the processor, while other contracts do not. For example, a DuPont high-oil corn contract specifies that farmers do not obtain any ownership rights to the crop because DuPont owns the crop; rather, farmers are caring for DuPont's property (Hamilton, 1999; Goodhue, 1999). Vukina and Leegomonchai (2004) observed similar contractual arrangements in the poultry industry, i.e., the processor holds the tile of ownership of chickens while the growers are compensated with fixed payments for raising chicken to market-weight. 
Second, Menard (1996, p.170) identified three types of contracts in the French poultry industry: fixed-price contracts; buy-and-sell contracts; and contracts of the putting-out type. Fixed-price contracts are agreements in which growers remain fully independent, and growers commit to deliver a certain quantity of chickens with specified characteristics at a certain date. Contracts of this type specify a fixed amount of money to be paid to growers. Buy-and-sell contracts are arrangements in which growers buy chicks and sell chicken, dealing with the same firm at both ends. Growers usually remain in charge of intermediate products, though there may be restrictive clauses. Contracts of the putting-out type are agreements in which growers are provided with chicks, food, equipment or they must get them from specific firms.

Third, contracts are different in the pricing provisions to farmers. Some contracts purchase farmers' products at fixed prices specified ex ante, some contracts use tournament pricing when compensating farmers and some contracts do not adopt market-based pricing.

These observations illustrate that contract farming is characterized by various rules and incentives to govern the parties involved. It raises the question: how are these rules and incentives designed and/or aligned to deal with a specific transaction/product? One tentative treatment to the above observations is pursued by ERS/USDA (2003; 2006) in distinguishing production contracts and marketing contracts. Agricultural contracts fall into these two broad groups, where the ownership of the contracted commodity is treated as one distinguishing feature. ERS/USDA (2006, p.6) claims, “. . . Under a production contract, the farmer provides a set of services to the contractor, who usually owns the commodity while it is being produced. The contract specifies the services to be provided by the farmer, the manner in which the farmer is to be compensated for the services, and specific contractor's 
responsibilities for provision of inputs. . . Marketing contracts focus on the commodity as it is delivered to the contractor, rather than on the services provided by the farmer. They specify a commodity's price or a mechanism for determining the price, a delivery outlet, and a quantity to be delivered.”

According to this classification, production contracts assign the ownership of transacted product to agricultural firms (i.e., contractor) while marketing contracts do not. This classification highlights that the allocation of decision rights between two parties varies among different contracts, however, it remains unclear under what circumstances a set of decision rights should be allocated to a party, and why ${ }^{1}$. This is important because the allocation of decision rights, as a way of coordinating activities across various production processes and motivating behaviour of various stakeholders, determines how effective contract farming is.

We address this gap by focusing on the details of decision rights in contractual arrangements commonly found under a contract farming governance structure. Decision rights in the form of authority and responsibility address the question 'Who has authority or control (regarding the use of assets)?'. Decision rights concern all rights and rules regarding the deployment and use of assets (Hansmann, 1996). They specify who directs the firm's activities. Our main research question is What determines the allocation of decision rights between farmer growers and downstream processors in contract farming? We proceed in five steps. First, we formulate the hypotheses regarding contract farming. Then, the research design is specified. Subsequently the data is presented and the result is formulated. The last section concludes.

\footnotetext{
${ }^{1}$ In addition, this classification is not always accurate in terms of ownership allocation in some cases. For example, growers may leave the ownership of the contracted commodity to the contractors under production contracts, whereas seed, chemical inputs, and/or specifying planting/growing methods may be clearly specified and/or provided under marketing contracts.
} 


\section{Contract farming hypotheses}

This section formulates hypotheses regarding the allocation of decision rights. The property rights model, i.e. GHM (Grossman and Hart (1986), Hart and Moore (1990)), addressed governance structure choice in the setting of incomplete contracting. They defined the ownership of assets as the holder of residual decision rights: the rights to make any decision regarding the use of an asset that is not explicitly attenuated by law or assigned to other parties by contract. Ownership of specific and non-contractible assets is important, because it affects ex ante investment incentives via the allocation of bargaining power ex post. Each governance structure choice involves benefits as well as costs, and the assignment of decision rights, hence ownership, should be allocated to the party who can create most value to a specific relation. Two hypotheses are therefore:

Hypothesis one: More decision rights will be allocated to the firm, if the level of firms' specific investment increases.

Hypothesis two: Less decision rights will be allocated to the firm, if the level of farmers' specific investment increases.

In agri-food transactions, bargaining power is also an important issue. Processors' bargaining power generated from financial means are larger compared with individual small farmers. However, this bargaining power may be strengthened or weakened by processors' competition status. If the processor has monopsonyoligopsony power, that is, there are no or just a few competitive buyers (including markets) within a certain geographical area, then farmers have less choice to sell their products. To gain access to marketing channels, farmers may give up their autonomy 
in making decisions for market access via contracts. Monopsony-oligopsony power thus can be transformed into bargaining power of the processor, and further induces more authority allocated to processors. Thus, we have

Hypothesis three: More decision rights are allocated to firms, if firms have more monopsony-oligopsony power.

The GHM model predicts that the allocation of ex post decision rights is determined by the desire to improve the ex ante specific investment. However, the allocation of decision rights in the contracts may be determined by a different mechanism. Arrunda, Garicano and Vazquez (2001) examined the allocation of rights and monetary incentives in automobile franchise contracts. The empirical findings show that all contracts substantially limit the decision rights of franchisees, and grant extensive implementation and enforcement powers to manufactures. It is suggested that a trade-off between the risk of ex post opportunism on the two sides (i.e., both franchisor automobile manufacturers and franchisee dealers) drives the allocation pattern of decision rights.

Similar to franchising, agricultural contracts also entail externalities at the producers' side. As agricultural products become more and more specialized, many contractors require high quality products by providing specific quality and safety attribute standards. However, quality attributes of agricultural commodities has inherently a high degree of heterogeneity (Ligon, 2002; Carriquiry and Babcock, 2004). This variability stems mainly from the randomness of the production environment and/or the heterogeneity of the practices employed by farmers. Ex post opportunism from processors in farmer-processor relationships is possible too. The 
centralized contract, that is the processor is in charge of most decisions, can result in opportunistic behavior by the processor (Bogetoft and Olesen, 2002). The processor may reject the delivery by downgrading quality attributes or ask for a discount on agreed-upon prices, when the market situation is not good for selling.

In line with Arrunda, Garicano and Vazquez (2001), we expect that decision rights allocation will be determined by the extent of the opportunism risks of the two sides in a specific supply chain. When high quality of contracted products is important for the processor, the costs of opportunism risks from growers are greater. In this case, more decision rights will be allocated to processors. When processors have a good reputation, the risks of hold-ups will be reduced, the willingness of accepting authority from processors will be increased. Thus, we expect the following two hypotheses to hold:

Hypothesis four: More decision rights are assigned to the firm, when the firm deals with higher quality products.

Hypothesis five: More decision rights are assigned to the firm, when the reputation of the processor is better recognized.

\section{Empirical analysis}

\subsection{Fruit and vegetable sector}

We focus on the fruit and vegetable sector for two main reasons. Firstly, the extent of contract farming varies a lot in the fruit and vegetable sector (USDA, 2006). There are simple contracts as well as complicated contracts, and there are highly restrictive contracts as well as quite autonomous contracts. Our preliminary observations on the fruit and vegetable sector in China confirm this. We visited four 
fruit and vegetable cooperatives in Eastern China two times in 2004 and in 2005. Various arrangements of vertical coordination and decision rights were observed. Thus, the fruit and vegetable sector provides the appropriate scenario for capturing the driving forces of our model. In contrast, concentration of decision rights by agricultural firms dominates in the pork industry and poultry industry.

Secondly, compared with livestock sectors such as poultry, pork and beef, fruits and vegetables have received less attention in the prior literature regarding decision rights.

\subsection{Multiple case study}

We adopt a multiple case study research strategy (Yin, 2003). A ‘case’ in our research is the contracting relationship between primary farmers (upstream growers) and agri-business (downstream processors, including all kinds of marketing and/or processing firms).

Data used in our research are mainly primary data, generated by face-to-face semi-structured interviews. It is useful to acquire written contracts, but written contracts can not be our major data source due to two reasons. Firstly, we expect it is difficult to gather commercial contracts because of the confidentiality issue. Secondly, we also consider oral contracts. Thus, interviews are the right data extraction method for our purpose, and whenever possible, written contracts will be collected and analyzed too to increase data reliability.

\subsection{Sample}

We have selected twelve fruit and vegetable contracting relations between farmers and agricultural firms from the Shandong province in China. Shandong province is located in eastern coastal China, and is chosen because it is well known for vegetable and fruit production. Three districts or counties in the Shandong 
province are chosen: Shouguang city, Laiyang city and Dezhou district to increase local variety. Shouguang and Laiyang are both famous for vegetable and fruit production, while Dezhou is particularly famous for one type of fruit, i.e., Chinese date. Shouguang and Laiyang are more developed than Dezhou. In addition, Shouguang is more domestic-oriented while Laiyang is more export-oriented. Each case is chosen by considering both variability regarding contracting practices and the researchers' access capability to the case companies. Table one and two summarize the involved vegetable or fruit business of each firm. ${ }^{2}$

Table 1: General information regarding the 12 cases

\begin{tabular}{|c|c|c|c|c|c|c|c|}
\hline $\begin{array}{l}\text { Character } \\
\text { istic } \\
\text { Firms } \\
\text { in cases }\end{array}$ & $\begin{array}{l}\text { Establish } \\
\text { ment }\end{array}$ & Location & ownership & $\begin{array}{l}\text { No. of } \\
\text { fixed } \\
\text { employee }\end{array}$ & $\begin{array}{l}\begin{array}{l}\text { Fixed } \\
\text { capital } \\
\text { (million }\end{array} \\
\text { Yuan) }\end{array}$ & $\begin{array}{l}2005 \\
\text { Sales } \\
\text { (million } \\
\text { Yuan) }\end{array}$ & $\begin{array}{l}\text { Gross } \\
\text { profitab- } \\
\text { ility }\end{array}$ \\
\hline Firm 1 & 1986* & Laiyang & Shareholding & 21,000 & & 26,020 & -- \\
\hline Firm 2 & 1994 & Laiyang & $\begin{array}{l}\text { Private joint } \\
\text { venture }\end{array}$ & 1,800 & & 1,200 & -- \\
\hline Firm 3 & 1992 & Shouguang & Shareholding & 200 & & 28 & -- \\
\hline Firm 4 & 2002 & Shouguang & Private & 180 & & 18 & -- \\
\hline Firm 5 & 2001 & Shouguang & $\begin{array}{l}\text { Limited } \\
\text { liability }\end{array}$ & 1800 & 83.1 & 42.2 & $20 \%$ \\
\hline Firm 6 & 1994 & Shouguang & Shareholding & 50 & 4 & & $20 \%$ \\
\hline Firm 7 & 1994 & Dezhou & $\begin{array}{l}\text { Limited } \\
\text { liability }\end{array}$ & 40 & 3.2 & 14 & $22.9 \%$ \\
\hline Firm 8 & 2003 & Dezhou & private & 248 & 6 & 1,500 & $20 \%$ \\
\hline Firm 9 & 2000 & Dezhou & private & 120 & 20 & 27 & $18.3 \%$ \\
\hline Firm 10 & 2000 & Dezhou & shareholding & 42 & 22 & 60 & $9.4 \%$ \\
\hline Firm 11 & 1998 & Dezhou & private & 35 & 1 & 1.85 & $20.5 \%$ \\
\hline Firm 12 & 1999 & Dezhou & shareholding & 1300 & 2,200 & 3,400 & -- \\
\hline
\end{tabular}

Table 2: Product information regarding the 12 cases

\begin{tabular}{lllll}
\hline Characteristic & $\begin{array}{l}\text { Percentage of } \\
\text { vegetable } \\
\text { business }\end{array}$ & $\begin{array}{l}\text { Percentage of } \\
\text { fruit } \\
\text { business } \\
\text { in cases }\end{array}$ & $\begin{array}{l}\text { Percentage of } \\
\text { export in } \\
\text { vegetable/fruit } \\
\text { business }\end{array}$ & Major vegetable/fruit \\
\hline Firm 1 & $\begin{array}{l}20 \% \text { in all } \\
\text { exports }\end{array}$ & -- & $60 \%$ & $\begin{array}{l}\text { spinach, broccoli, } \\
\text { capsicum, burdock, } \\
\text { green soy bean, snow } \\
\text { pea } \\
\text { spinach, broccoli, } \\
\text { capsicum, green soy } \\
\text { bean, snow pea }\end{array}$ \\
\hline
\end{tabular}

\footnotetext{
${ }^{2}$ The real names and contact details of the interviewed firms and the title of the interviewees are in Hu (2007, appendix 4.3).
} 


\begin{tabular}{|c|c|c|c|c|}
\hline Firm 3 & $99 \%$ & -- & $100 \%$ & $\begin{array}{l}\text { garlic, carrot, capsicum, } \\
\text { ginger }\end{array}$ \\
\hline Firm 4 & $100 \%$ & -- & $0 \%$ & $\begin{array}{l}\text { seasonal vegetables such } \\
\text { as tomato, cucumber, } \\
\text { eggplant }\end{array}$ \\
\hline Firm 5 & $40 \%$ & -- & $100 \%$ & \\
\hline Firm 6 & $50 \%$ & -- & $0 \%$ & French shepherd's-purse \\
\hline Firm 7 & $30 \%$ & -- & $0 \%$ & capsicum \\
\hline Firm 8 & $70 \%$ & -- & $2 \%$ & $\begin{array}{l}\text { Cabbage, capsicum, } \\
\text { carrot, garlic }\end{array}$ \\
\hline Firm 9 & $50 \%$ & -- & $100 \%$ & capsicum \\
\hline Firm 10 & $100 \%$ & -- & $100 \%$ & $\begin{array}{l}\text { Leek, green Chinese } \\
\text { onion, capsicum }\end{array}$ \\
\hline Firm 11 & -- & $90 \%$ & $0 \%$ & Chinese date \\
\hline Firm 12 & -- & $40 \%$ & $10 \%$ & Chinese date \\
\hline
\end{tabular}

Firm one to ten are involved in vegetable contracting, while firm eleven and firm twelve are in fruit contracting. None of the firms are state-owned firms. Firm one is the oldest firm and established in 1986. Firm seven is the youngest firm and established in 2003. The size of the firms varies a lot, measured in terms of permanent employees, fixed capital or sales turnovers. Regarding diversification/specialization, firms two, three, four, five, seven, nine, ten mainly deal with vegetables and firm eleven mainly deals with Chinese date, while the remaining firms one, five, seven, eleven also deal with other products. Regarding marketing channels, firms two, three, five, nine and ten export all vegetables to foreign markets, and firm one targets both foreign and domestic markets, while the remaining firms mainly or wholly target domestic markets.

\subsection{Measurements}

The measurement issue of the independent variable and the explanatory variables are addressed in this subsection. We use several tactics to address the validity and reliability of our measurements. Firstly, we review the high-quality empirical studies on a similar topic to see how they measure similar concepts. If their way of measuring can be applied to our research, we replicate their approaches. For example, measuring 
decision rights allocated to firms, specific investment by firms/farmers, monopsonyoligopsony power, are approached in this way. Secondly, for some measures such as the measurement for reputation and quality, we ask both peer researchers and professionals/experts to check the accurateness since we develop them by ourselves. Thirdly, we pilot-test the semi-structured questionnaire by asking several people: a Chinese researcher specialized in agricultural institutions and organizations; a Chinese researcher specialized in finance but quite familiar with rural societies; a senior local officer who was once responsible for both industry and agriculture development in local district; two local officers who are currently working in agricultural supervision and regulation agencies; a manager in a agricultural firm. The final English and Chinese versions of the questionnaire are included as appendices in $\mathrm{Hu}$ (2007). The fourth tactic to guarantee this validity is to use multiple sources of evidence. We use individual interviews, group interviews, on-site observations, casual talks with farmers and textual materials to generate evidence. In addition to these data collection tactics, we also telephoned one key interviewee to generally illustrate our findings in the stage of composing reports. Finally, we develop a case study database to establish reliability. All the interviewee's talks and answers are written down by us as much as possible during the interview. When allowed, we record the whole interview. Both the textual documents and tapes are kept for reference.

\section{Decision rights allocated to firms}

Decision rights are a set of rights to direct activities or decide how to use assets. We distinguish input decision rights, in-process decision rights, after-process decision rights, monitoring decision rights and termination decision rights and some other decision rights. We add up the number of rights allocated to one party (i.e., firms in our analysis) as the index of authority allocated to one party. This method has 
been adopted in several empirical studies (Arrunada, Garicano, and Vazquez, 2002; Lerner and Merges, 1998). ${ }^{3}$ Of course, simply adding up the number of decision rights has problems, because it treats each decision right with the same weight. To partly deal with this problem, we will further look into each sub-group.

\section{Quality}

Quality is measured by the quality standards adopted by firms when procuring and marketing products. In China, there are three levels of national quality certification: NPF (Non-Pollution Food), GF (Green Food), OF (Organic Food). Vegetables with these national certifications are thought to have higher quality than non-certified vegetables. In addition, some vegetables are sold under international quality certifications. Three values regarding quality are identified: 'High’ if a firm specifies/requires Organic Food Standards or any international quality standards which equals or is stricter than Organic Food, 'Medium' if a firm specifies/requires Green Food Standard or No Pollution Food Standards, and 'low' if the above two cases does not apply.

\section{Reputation}

Arrunada, Garicano, and Vazquez (2001) measure reputation by the length of the relationship between two contract parties. For our purpose, this measurement for reputation is not satisfactory, because contract farming is a new phenomenon in China and thus contracting experience may not vary enough among different firm-farmer supply chains. We use two kinds of measurements. The first measurement is brand name capital. If a firm has invested substantially in its brand and accumulated brand

\footnotetext{
${ }^{3}$ Elfenbein and Lerner (2003) adopt another method: they distinguish two sets of decision rights in the contractual relationship between a portal and its partner. For one set of decision rights that could be assigned to either party, a provision is coded as +1 if it favours portal, -1 if it favours the partner, and 0 if neutral. For the second set of decision rights that mainly limited the activities for the partner, they code +1 if such limitation rights are present and 0 if absent. Since our research is mainly focused on decision rights allocated to a firm, we decide to use the first method.
} 
name capital, the firm is more likely to develop and sustain reputation. Based on the overall answers, brand name capital is ranked as one of three levels with decreasing order: national-recognized, local-recognized, and no-brand.

A second measurement is official honor/award. In China, governments still play an important role in coordinating and/or supervising enterprises, although they do not intervene in the operations of enterprises any more in most cases. Such honor/awards normally consider the size of a firm, the farmers a firm is dealing with, share of the market, community contributions, employment, etc. We distinguish four values regarding the measurement: 'national honors/awards' if a firm receives some honors/awards from the central governments, 'provincial honors/awards' if a firm receives some honors/awards from provincial governments, 'local' honors/awards if a firm receives some honors/awards from local governments, and 'no official honors/awards' if a firm receives no honors/awards from any government. These four levels of official honors/awards represent the level of reputation in decreasing order.

\section{Uncertainty}

Uncertainty is a complex concept. Behavioral uncertainty is an important focus in transaction cost economics and supply chain management (see for example, Kwon and Suh, 2004). For our purpose, we mainly focus on uncertainty of the environment. In an uncertain environment, firms have difficulties to predict supply and demand and the price may fluctuate a lot. We use the difficulty level of predicting the market (price and supply, demand) to measure uncertainty. These five scales can be transformed into three levels of uncertainty: one and two for 'low' uncertainty; three for 'medium' uncertainty, and four and five for 'high' uncertainty. 
Joskow summarizes Williamson's four types of asset specificity as site specificity, physical specificity, human specificity, and dedicated assets (Joskow 1988; and Williamson 1983). We address both physical capital specificity and human capital specificity. Five questions were asked to measure the overall level of specific investment: the first two questions require the interviewee to evaluate the physical investment in procuring, processing and marketing products and potential loss in case of changing or closing current business. The third and fourth questions ask the interviewee to evaluate the training practice to employees on procuring, processing and marketing and potential loss in case of changing or closing current business. The fifth question asks the interviewee to evaluate the investment on quality control. All answers are scaled from one to five in ascending order: one refers to no specific investment and five the highest level of specific investment. By summarizing the five answers, we obtain a measure of the level of firm's specific investment.

\section{Farmers' specific investment}

Farmers' specific investment is measured by two aspects: physical specific investment and human capital investment. Since we interview the firms instead of farmer growers in our research, it is difficult and not feasible to find contracted growers to answer the two questions. Alternatively, we ask the interviewees to evaluate farmer's specific investment. Better measurements can be acquired when the interviewees are both familiar with farmers' operations and judge the level of investment fairly. During the interviews, we verified that the interviewees are familiar with farmers' activities. However, the validity of the measurement may be influenced by the interviewee' arbitrary judgment. It implies that we have to be especially cautious when drawing any conclusion by using this measurement. 


\section{Monopsony-oligopsony power}

We distinguish three possibilities regarding the degree of a firm's monopsony-oligopsony power. If in a given area, farmers can only sign contracts with one firm, then the firm is perceived to have 'high' monopsony-oligopsony power; if farmers can sign contracts with more than one but less than five firms, then the firm is perceived to have 'medium' monopsony-oligopsony power; if farmers can sign contracts with more than five potential firms, then firms are perceived to have 'low' monopsony-oligopsony power.

\section{Data regarding decision rights}

This section illustrates contract arrangements in terms of the allocation of decision rights. The decision rights are listed in table three. We will look into several sub-groups of decision rights. Firstly, the twelve cases show some decision rights variations regarding input. For the four potential input control activities, major firms have allocated two or three: five firms have the rights to control seed, fertilizer and pesticide, and one firm controls fertilizer and pesticide. Firm seven and eleven allocates only one decision right, while firms seven and nine do not control inputs. No firm has decision rights regarding planting, irrigation and cropping facilities to be used by growers. One reason for major firms controlling fertilizer and pesticide may be related with the specific industry in this study, i.e., vegetable and fruit industry. The quality (e.g. safety attribute) of vegetables is highly dependent on what fertilizer/pesticide to use and how to use them. The manager in firm one tells us, "when and how to use pesticide is very important to control quality. We send technicians to inspect the fields two times a week. It is required that our quality guarantee staffs must be on-site when growers spread pesticide. Our quality guarantee staffs will supervise what pesticides to use and the compounding of pesticides. The 
use of pesticides before harvesting is especially important for us. We call the ten days from pesticide spreading to harvesting 'Pesticide Security Management Period'. During these ten days, the fields will be supervised twenty four hour around.’’

Table 3: Decision rights allocated to agricultural firms

\begin{tabular}{|c|c|c|c|c|c|c|c|c|c|c|c|c|}
\hline $\begin{array}{ll}\text { Case } \\
\text { Decision rights }\end{array}$ & 1 & 2 & 3 & 4 & 5 & 6 & 7 & 8 & 9 & 10 & 11 & 12 \\
\hline Price of delivery & $x$ & $x$ & & & & & $x$ & & & & & \\
\hline Quantity of delivery & & & & & & & $x$ & & & & & \\
\hline Quality specification & $x$ & $x$ & $x$ & $x$ & $x$ & $x$ & $x$ & $x$ & $x$ & $x$ & $x$ & $x$ \\
\hline Input control & 3 & 3 & 3 & 2 & 3 & 3 & 1 & 0 & 0 & 3 & 1 & 3 \\
\hline Specified/provided seeds & $x$ & $x$ & $x$ & & $x$ & $x$ & & $x$ & & $x$ & & $x$ \\
\hline Specified/provided fertilizer & $x$ & $x$ & $x$ & $x$ & $x$ & $x$ & & & & $x$ & & $x$ \\
\hline $\begin{array}{l}\text { Specified/provided } \\
\text { pesticide } \\
\text { Specified/provided } \\
\text { planting, irrigation, } \\
\text { cropping equipments }\end{array}$ & $x$ & $x$ & $x$ & $x$ & $x$ & $x$ & & & & $x$ & $x$ & $x$ \\
\hline In-process control & 5 & 5 & 2 & 1 & 5 & 3 & 1 & 0 & 1 & 5 & 1 & 5 \\
\hline Planting plan & $x$ & $x$ & & & & & & & & & & \\
\hline Plowing & & & & & $x$ & $x$ & & $x$ & $x$ & $x$ & & \\
\hline Seeding & & $x$ & & & $x$ & & & & & $x$ & & \\
\hline Cultivating & $x$ & $x$ & $x$ & $x$ & $x$ & & & & & & & $x$ \\
\hline Use of fertilizer & $x$ & & & & & & & & & $x$ & & $x$ \\
\hline Use of pesticide & $x$ & $x$ & & & & & & & & $x$ & $x$ & $x$ \\
\hline Harvesting & $x$ & $x$ & $x$ & & $x$ & $x$ & & & & & & $x$ \\
\hline After-process control & 5 & 5 & 6 & 4 & 6 & 5 & 4 & 5 & 3 & 4 & 4 & 3 \\
\hline Packing before delivery & $x$ & $x$ & $x$ & & $x$ & & & & & & & \\
\hline Storing before delivery & & & $x$ & & $x$ & $x$ & $x$ & & & & & \\
\hline Delivery time/place & $x$ & $x$ & $x$ & $x$ & $x$ & $x$ & $x$ & $x$ & & & & \\
\hline Quality measuring & $x$ & $x$ & $x$ & $x$ & $x$ & $x$ & $x$ & $x$ & $x$ & $x$ & $x$ & $x$ \\
\hline $\begin{array}{l}\text { Sorting, sizing, grading, } \\
\text { packing for weighing and } \\
\text { labeling }\end{array}$ & $x$ & $x$ & $x$ & $x$ & $x$ & $x$ & $x$ & $x$ & $x$ & $x$ & $x$ & $x$ \\
\hline labeling & $x$ & $x$ & $x$ & $x$ & $x$ & $x$ & $x$ & $x$ & $x$ & $x$ & $x$ & $x$ \\
\hline Monitoring rights & 3 & 3 & 2 & 2 & 2 & 2 & 2 & 2 & 2 & 2 & 2 & 2 \\
\hline Fulfillment of delivery & $x$ & $x$ & $x$ & $x$ & $x$ & $x$ & $x$ & $x$ & $x$ & $x$ & $x$ & $x$ \\
\hline $\begin{array}{l}\text { Direct inspection of } \\
\text { growers }\end{array}$ & $x$ & $x$ & $x$ & $x$ & $x$ & $x$ & $x$ & $x$ & $x$ & $x$ & $x$ & $x$ \\
\hline $\begin{array}{l}\text { Grower' duty to provide } \\
\text { field records }\end{array}$ & $x$ & $x$ & & & & & & & & & & \\
\hline Termination rights & $x$ & $x$ & & $x$ & & & $x$ & & $x$ & & & \\
\hline $\begin{array}{l}\text { Decision Rights by firms: } \\
\text { Total }\end{array}$ & 19 & 19 & 14 & 11 & 17 & 14 & 10 & 11 & 8 & 20 & 9 & 14 \\
\hline
\end{tabular}

Secondly, the twelve cases demonstrate variation regarding in-process decision rights. For the seven potential control activities, five firms allocate five decision rights, and one firm allocates three. five firms have only one or two decision rights, while for one firm (i.e. case seven) no decision rights are allocated at all. It is 
worth mentioning the decision rights regarding cultivating and harvesting here. In the majority of the cases, cultivating and/or harvesting is controlled by firms somehow. Growers are required to grow according to the firms' technical guidance and the field management requirement or guidebooks. Growers are still taking care of the daily cultivating operations, however, these operations must be aligned with the firm's requirements. Most firms send their technicians to supervise and guide the growing activities.

Thirdly, the twelve cases have many similarities in allocating after-process decision rights. For the five potential control activities, twelve firms are allocated more than three decision rights. All twelve firms have rights to measure quality, to sort, size and grade, and to label. In all twelve cases except two (i.e., cases nine and twelve) delivery time and/or place is decided by firms. Three points should be mentioned here. Firstly, three firms (cases one, two and four) clearly state that they make calls to growers when they need products, the products are delivered immediately after harvesting. Several firms claim that they have rights to decide delivery time and place, although the way of informing growers are not told. Secondly, firms have rights to tell a farmer how to store before delivery. For example, firm three is mainly processing and exporting processed garlic, which is less perishable than fresh vegetables such as spinach. It may be the reason why growers store the harvest for some time before delivery. Thirdly, no growers have rights to measure the quality of their delivery. This right is allocated completely to firms. In all twelve cases, no third-party is involved.

Fourthly, regarding monitoring rights, the fulfillment of delivery and the rights of direct field visits are allocated to firms in all twelve cases, while two firms (cases one and two) additionally ask growers to record their field operations. 
Fifthly, regarding termination rights, in five cases firms are allocated the rights to terminate contracts by judging if growers breach contractual terms, while in the remaining seven cases clauses specify when to terminate contracts legally.

Sixthly, regarding quality specification rights, firms have the right to specify the exact quality requirement.

Seventhly, regarding the decisions on price and quantity, in the majority of the cases they are ex ante specified in contracts, thus firms or farmers are not allowed to decide by themselves. However, in case seven the firm has rights to decide the quantity, while in case five the farmers decide how much to deliver. In the cases one and two, the firms have rights to decide the price.

The questions and answers in the interviews are transferred to the measurement of different variables which will be used further to test hypotheses. Table four summarizes the measurements of the variables in the twelve cases.

Table 4: Independent variables and dependent variables (to be continued)

\begin{tabular}{|c|c|c|c|c|c|c|}
\hline $\begin{array}{ll} & \text { Case } \\
\text { Variable } & \end{array}$ & Case 1 & Case 2 & Case 3 & Case 4 & Case 5 & Case 6 \\
\hline $\begin{array}{l}\text { Dependent } \\
\text { Variable } \\
\text { decision rights } \\
\text { allocated to firms }\end{array}$ & $\begin{array}{l}\text { High } \\
\text { (19) }\end{array}$ & $\begin{array}{l}\text { High } \\
(19)\end{array}$ & $\begin{array}{l}\text { Medium } \\
(14)\end{array}$ & $\begin{array}{l}\text { Medium } \\
\text { (11) }\end{array}$ & $\begin{array}{l}\text { High } \\
(17)\end{array}$ & $\begin{array}{l}\text { Medium } \\
\text { (14) }\end{array}$ \\
\hline $\begin{array}{l}\text { Independent } \\
\text { Variables }\end{array}$ & & & & & & \\
\hline $\begin{array}{l}\text { quality } \\
\text { reputation }\end{array}$ & High & High & Medium & Medium & High & Medium \\
\hline $\begin{array}{l}\text {-brand name } \\
\text { capital }\end{array}$ & $\begin{array}{l}\text { National } \\
\text { recognized }\end{array}$ & $\begin{array}{l}\text { Local } \\
\text { recognized }\end{array}$ & No brand & $\begin{array}{l}\text { Local } \\
\text { recognized }\end{array}$ & $\begin{array}{l}\text { Local } \\
\text { recognized }\end{array}$ & $\begin{array}{l}\text { Local } \\
\text { recognized }\end{array}$ \\
\hline $\begin{array}{l}\text {-official } \\
\text { honor/award }\end{array}$ & national & provincial & local & local & provincial & $\begin{array}{l}\text { No honor/ } \\
\text { award }\end{array}$ \\
\hline uncertainty & Medium & Medium & Medium & Low & High & Medium \\
\hline $\begin{array}{l}\text { firm's specific } \\
\text { investment }\end{array}$ & High & High & High & Low & High & Medium \\
\hline $\begin{array}{l}\text { farmer's specific } \\
\text { investment }\end{array}$ & Low & Low & Low & Low & Medium & Low \\
\hline $\begin{array}{l}\text { monopsony- } \\
\text { oligopsony power }\end{array}$ & Medium & Medium & Low & High & High & High \\
\hline
\end{tabular}


Table 4: Independent variables and dependent variables (continued)

\begin{tabular}{|c|c|c|c|c|c|c|}
\hline $\begin{array}{ll} & \text { Case } \\
\text { Variable } & \\
\end{array}$ & Case 7 & Case 8 & Case 9 & Case 10 & Case 11 & Case 12 \\
\hline $\begin{array}{c}\text { Dependent } \\
\text { Variable } \\
\text { decision rights } \\
\text { allocated to firms } \\
\text { Independent } \\
\text { Variables }\end{array}$ & $\begin{array}{l}\text { Medium } \\
\text { (10) }\end{array}$ & $\begin{array}{l}\text { Medium } \\
\text { (11) }\end{array}$ & $\begin{array}{l}\text { Medium } \\
\text { (8) }\end{array}$ & $\begin{array}{l}\text { High } \\
(20)\end{array}$ & $\begin{array}{l}\text { Medium } \\
\text { (9) }\end{array}$ & $\begin{array}{l}\text { Medium } \\
\text { (14) }\end{array}$ \\
\hline $\begin{array}{l}\text { quality } \\
\text { reputation }\end{array}$ & Medium & Medium & Low & High & Medium & Medium \\
\hline $\begin{array}{l}\text {-brand name } \\
\text { capital }\end{array}$ & $\begin{array}{l}\text { Local } \\
\text { recognized }\end{array}$ & $\begin{array}{l}\text { Local } \\
\text { recognized }\end{array}$ & No brand & No brand & No brand & $\begin{array}{l}\text { Local } \\
\text { recognized }\end{array}$ \\
\hline $\begin{array}{l}\text {-official } \\
\text { honor/award }\end{array}$ & local & provincial & local & provincial & $\begin{array}{l}\text { No honor/ } \\
\text { award }\end{array}$ & provincial \\
\hline uncertainty & Medium & Medium & High & Medium & Low & Medium \\
\hline $\begin{array}{l}\text { firm’s specific } \\
\text { investment }\end{array}$ & Low & Medium & Low & Medium & Low & Low \\
\hline $\begin{array}{l}\text { farmer's specific } \\
\text { investment }\end{array}$ & Low & Low & Low & Low & Low & Low \\
\hline $\begin{array}{l}\text { monopsony- } \\
\text { oligopsony power }\end{array}$ & Medium & High & Medium & High & Medium & Medium \\
\hline
\end{tabular}

It is worth formulating several remarks regarding table four. Firstly, regarding decision rights allocated to firms, we first calculated the number of decision rights assigned to a firm (the result is listed in the last row in table four). Then, the cardinal number of decision rights allocated to a firm is further transformed to an ordinal ratio to facilitate the testing (see row three in table four). In each case, the firm's actual decision rights are divided by twenty three (i.e., the total number of possible decision rights allocated either to firms or to farmers in our research). If the ratio is smaller than 0.34 , then the firm is perceived as allocating a 'low' proportion of all decision rights (i.e., less decision rights are allocated to firms); if it is between 0.34 and 0.67 , then the firm is perceived as allocating a 'medium' proportion of all examined decision rights; if it is larger than 0.67 , then the firm is perceived as being allocated 'high' proportion of all decision rights. It is obvious that 'high'-marked firms have 
more decision rights compared with 'medium'-marked firms, and the same with 'medium'-marked firms and 'low'-marked firms. ${ }^{4}$

Secondly, regarding firms’ specific investment, quantitative measures from five questions are first added up, and then the sum is divided by five to obtain the equally weighted total measure for this variable. To facilitate testing, this numerical measure is further transformed to an ordinal one. If it is smaller than three, then the firm's specific investment level is perceived to be 'low'; if it falls between three and four, then the firm's specific investment level is perceived to be 'medium'; If it is larger than four, then the firm's specific investment level is perceived to be 'high'.

The same rule applies to farmers’ specific investment.

\section{Results}

This section presents the results in terms of the five hypotheses.

\subsection{Decision rights allocated to firms and firm's specific investment}

In the twelve cases, firms make specific investments regarding physical investment as well as human capital investment. In four cases, the firm perceives its specific investments to be at a high level, and three cases classify its specific investment at a medium level, while the firm in five cases classifies its specific investment as a low level.

For the five cases with low firm's specific investment, the proportion of decision rights allocated to firms is all ranked as 'medium'. As the firm's specific investment is increased from a low level to a medium level, the proportion of decision

\footnotetext{
${ }^{4}$ Another way to transforming this cardinal number to ordinal number is to first calculate the average value of all ratios. In our case, it is $7.23 / 12=0.6$. Then, the firm with a ratio larger than 0.6 can be perceived to have more decision rights than the firm with a ratio smaller than 0.6. In this way, there are only two values: high or low. We did do this calculation as a way to check the reliability of the main-text transforming tactic, and the result shows that the two methods do not differ much.
} 
rights allocated to firms remains at a medium level (cases five and seven) or increase to a high level (case ten). As the firm's specific investment is further increased from a medium level to a high level, three cases shows that the proportion is increased to a high level too, and only one case remains at the same medium level. What we learn from the four cases is, therefore, as specific investment is increased, the decision rights allocated to firms are increased as well. That is to say, the level of specific investment by firms is positively related with the decision rights allocated to firms.

\subsection{Decision rights allocated to firms and farmer's specific investment}

In eleven cases, the farmer grower is thought to have a low level of specific investment, and only one case (case five) perceives the farmer grower to be at a medium level of specific investment. For the cases with low farmer's specific investment, the proportion of decision rights allocated to firms is either high (in three cases) or medium (in seven cases). As the farmer's specific investment is increased to a higher level, the proportion of decision rights allocated to firms is increased to a higher level too (see case five), which is contrary to our prediction. Thus, the hypothesis regarding a negative relationship between farmer’s specific investment and decision rights allocated to firms is not supported. It means that farmer's specific investment is not the determining factor regarding the allocation of decision rights. The reason may be, although farmers made specific investment, this investment seems to be too limited to drive farmers in the direction of more decision rights.

\subsection{Decision rights allocated to firms and monopsony-oligopsony power}

In all twelve cases, firms have some monopsony-oligopsony power. This is in accordance with the fact that farmer growers are weak in most transactions. In five cases, the firm is perceived to have a high level of monopsony-oligopsony power, and 
in six cases, the firm has a medium level of monopsony-oligopsony power, while only in one case (i.e., case three) the firm has a low level of monopsony-oligopsony power.

It is interesting to point out that the size of a firm is not the reason determining the level of monopsony-oligopsony power. For example, firm four is rather small in terms of permanent employees or in terms of fixed capital investment, however, this firm is perceived to have a larger bargaining power. Two reasons may explain high monopsony power. One factor is the market in which the firm operates. Take case four as example again. This firm mainly deals with fresh vegetables in domestic markets. When asked about the competitiveness of the market in which the firm operates, we were told that the competition is not very intensive. The reason is that they develop a market niche by making use of the rapid rise of supermarkets. The firm signs contracts with supermarkets to supply them with high-quality fresh vegetables. Since most agricultural firms around this firm are less sensitive to the development of supermarkets, it establishes its success in marketing to supermarkets. The other factor is the size of growers from whom the firm procures vegetables. Larger growers may have more channels to market their products, and may attract more firms to do business with them. In contrast, small farmers have fewer alternatives to contract with other firms because they are small in size and may lack a good reputation. For example, in case one where the largest firm with only medium monopsony-oligopsony power, the smallest contracted landing scale for one grower is one hundred mu. However, the small firm in case four contracts with more than two hundred farmers, and each farmer's contracting land is only around two or three mu.

For the case with low monopsony-oligopsony power, the proportion of decision rights allocated to firms is ranked as medium. As the monopsony-oligopsony power is increased to a medium level, the proportion of decision rights allocated to 
firms either remains at a medium level (in four cases) or increases to a high level (in two cases). As the proportion of decision rights allocated to firms is further increased to a high level, two cases show a high level of the proportion of decision rights allocated to firms and two cases show a medium level of the proportion of decision rights allocated to firms. Therefore, the hypothesis regarding a positive relationship between firm' monopsony-oligopsony power and allocated decision rights is partly supported.

\subsection{Decision rights allocated to firms and quality}

The data shows that four cases require high quality products while seven cases require medium quality products. Regarding the high quality cases, case one specifies high quality standards based on Japanese strict regulation on pesticide residuals, case two specifies high quality standards based on ISO9002 and HACCP, case ten is certified with IS09000 and HACCP, and case five requires strict Organic Food standards. The remaining cases, except case nine, specify relatively lower quality standards based on national quality standards Non-Pollution Food and Green Food. Notice that case nine is the only one being thought of low-quality. The interviewee in this case claimed that the firm required the farmers to meet Non-pollution Food quality, however, we found, after the detailed discussion, that this firm's vegetables were not certified as NPF at all, and no detailed quality requirement equivalent to NPF was specified in the contracts. Thus, compared with the other cases, the quality requirement in case nine is rather low.

In the four high quality cases, i.e., case one, two, five, and ten, the proportion of decision rights allocated to firms are marked as 'high', which means more decision rights are allocated to firms. As the quality standard requirement is decreased to a medium level in the cases three, four, five, seven, seven, eleven, and twelve, the 
proportion of decision rights allocated to firms is also decreased to 'medium' and thus less decision rights are allocated to firms. As the quality standard requirement is further decreased to a low level in case nine, the proportion of decision rights to firms remains at the 'medium' level. However, further compared with the exact number of decision rights to firms in all medium-quality cases, the firm in case nine has the least decision rights, i.e., seven (see the last row in table four). Therefore, the data shows that quality is positively related with the decision rights allocated to firms, thus hypothesis four is supported.

\subsection{Decision rights allocated to firms and reputation}

Two kinds of measurements are adopted to measure reputation: brand name capital and official honor/award. Firstly, let us look at the first measurement of reputation: brand name capital. The twelve cases exhibit large differences. The firm in case one has a national well-recognized brand. In 2005, the firm spent 1,000,000 Yuan in advertising. The firms in cases two, four, five, five, seven, seven and twelve have well-recognized local brands, while the firm in the cases three, nine, ten and eleven have no registered brands at all.

The interviews indicate that firms may not be very interested in establishing brands. For example, in case one, although the advertising fee is large compared with the other cases, the fee is quite small compared with its sale volume (i.e., 2.6 billion Yuan). The manager told us that the advertisement is mainly for selling vegetable and related products in domestic markets. If products are only sold abroad, managing and maintaining the relationships with old customers are more important than acquiring recognition in foreign markets. In other word, if not for domestic marketing, the firm will not spend too much in advertising. This consideration is also reflected in other cases. The general director also showed no interest in advertising the firm's brand in 
case two. We were told that managers having a good relationship with large foreign customers are vital for the success of a firm, not any brand on itself. In case three, the manager even told us directly his firm will not waste the money in registering a brand. Compared with these foreign-market-oriented firms, domestic-market-oriented firms hold different views regarding brands and advertisement. For example, in case four where the firm is mainly active in the domestic market, the two interviewees agree that branding is important. The firm spent 6,000 Yuan in advertising in 2005.

We cannot draw a conclusion regarding the brand name capital and decision rights allocation. In case one, a national-recognized brand name is associated with a high proportion of decision rights allocated to the firm. When brand name capital decreases from a national-recognized level to a local-recognized level, the proportion of decision rights allocated to firms either maintain a high level (see cases two and five) or decrease to a medium level (see cases four, five, seven, seven and twelve). Till now, it seems that there may be a positive relationship between the two variables. However, as brand name capital further decreases (i.e., no registered brands), the proportion of decision rights allocated to firms still maintains a medium level (see cases three, nine and eleven) or even increase to a high level (see case ten). Thus, the data does not show the predicted relationship.

Secondly, let us check the second measurement of reputation: official honor/award. The twelve cases are distinguished by considering four levels regarding official honors/awards. One case (i.e., case one) has several national honors/awards, five cases have several provincial honors/awards, and four cases have several local honors/awards, while two cases have no official honor/award. In detail, the firm in case one is the most well recognized, because it is awarded 'national dragon-head enterprise' and meanwhile acquired several national awards such as '500 Leading 
China Manufacturing Enterprise’, 'One hundred Leading China Food Enterprise’, etc. The firms two, five, seven, ten and twelve acquire several honors or awards from provincial governments, such as 'provincial dragon-head enterprise'. The firms three, four, seven and nine are honored or awarded as 'local dragon-head enterprise' by local governments. In the cases five and eleven, the two firms claim they have not acquired any honors/awards from local governments.

The relationship between official honor/award and decision rights allocated to firms is investigated now. For the one case with national honors/awards, the proportion of decision rights allocated to firms is high. For the four cases with provincial honor/award, it is either high (see cases two, seven and ten) or medium (see case twelve). For the four cases with local honors/awards, it is all medium, while for the two cases with no honor/award, it is medium. Thus, as the firm acquires a higherranked government honors/awards, which implies that the reputation is more established and recognized at a larger scale than the local environment, more decision rights are allocated to firms. Therefore, the data shows that there is a positive relationship between reputation, measured by official honor/award, and decision rights allocated to firms. It means that hypothesis five regarding a positive relationship between reputation, measured by official honor/award, and decision rights allocated to firms is supported.

\subsection{Summary}

We summarize the empirical results in table five. Among the five hypotheses, three are supported, one is partly supported, and one is not supported. The main findings are as follows. When the firm deals with a high quality product, has a well-recognized reputation, and has made substantial specific investments, more decision rights will be allocated to the firm when contracts are signed. 
Table 5: Empirical results

\begin{tabular}{|c|c|c|c|c|}
\hline Hypothesis & Dependent Variable & Independent variable & $\begin{array}{l}\text { Predicted } \\
\text { sign }\end{array}$ & $\begin{array}{l}\text { Empirical } \\
\text { result }\end{array}$ \\
\hline 1 & $\begin{array}{l}\text { Decision rights allocated } \\
\text { to firms }\end{array}$ & $\begin{array}{l}\text { Firm’s specific } \\
\text { investment }\end{array}$ & + & Supported \\
\hline 2 & $\begin{array}{l}\text { Decision rights allocated } \\
\text { to firms }\end{array}$ & $\begin{array}{l}\text { Farmer’s specific } \\
\text { investment }\end{array}$ & - & $\begin{array}{l}\text { Not } \\
\text { supported }\end{array}$ \\
\hline 3 & $\begin{array}{l}\text { Decision rights allocated } \\
\text { to firms }\end{array}$ & $\begin{array}{l}\text { monopsony- } \\
\text { oligopsony power }\end{array}$ & + & $\begin{array}{l}\text { Partly } \\
\text { supported }\end{array}$ \\
\hline 4 & $\begin{array}{l}\text { Decision rights allocated } \\
\text { to firms }\end{array}$ & Quality & + & Supported \\
\hline 5 & $\begin{array}{l}\text { Decision rights allocated } \\
\text { to firms }\end{array}$ & Reputation & + & Supported \\
\hline
\end{tabular}

\section{Conclusion and further research}

We empirically examine the determinants of the allocation of decision rights in the context of fruit and vegetable contracting. The main conclusion is that under contract farming, many decision rights are shifted from farmers to firms. Quality, reputation and specific investments by firms positively influence the number of decision rights allocated to agri-business firms under contract farming, while monopsony-oligopsony power and specific investments by farmers have no effect on the allocation of decision rights. It indicates that ex ante as well as ex post considerations have to be taken into account when explaining the allocation of decision rights.

Our research contributes, in general, to the recent empirical work on firm's boundary. One of the main findings shows that contracts allocate decision rights across fixed firm boundaries. This is consistent with many other studies (for example, Lerner and Mergers, 1998; Elfenbein and Lerner, 2003; Arrunada, Garicano, and Vazquez, 2001). It implies that the boundary of a firm is changed even though the ownership remains the same. Another finding is that asset specificity, together with other factors, determines the extent of decision rights centralization. Thus, it supports 
the key proposition of the Transaction Cost Economics that integration is correlated with asset specificity. Our research contributes, in specific, to the empirical literature regarding the allocation of decision rights. It goes further than the previous studies regarding agricultural contracts in that it analyze the whole system of allocation of rights over substantive decisions. It illustrates who owns what decision rights on the one hand, and identifies the underlying factors driving a certain pattern of authority allocation on the other hand. Arrunada, Garicano, and Vazquez (2001; 2005) are most close to our research. They demonstrate that the allocation of decision rights and incentive intensity differ across brands and this variation is explained by the incidence of moral hazard in the context of automobile franchising contracts. We extend their observations from the franchising field to the contract farming field.

Future research may be along the standard lines, but therefore not less important. It may be geared to collecting more data. New cases will help to test the robustness of our findings. Especially, regression analysis can be adopted and add additional value to the generalization issue if more than fifty cases are selected. Second, this research is focused on the fruit and vegetable sector. Other sectors will again help to test the robustness of our findings.

\section{References}

Arrunada, B., Garicano, L. and Vazquez, L., 2001. Contractual allocation of decision rights and incentives: the case of automobile distribution. Journal of Law, Economics and Organization, 17(1), 257-284.

Arrunada, B., Garicano, L. and Vazquez, L., 2005. Completing contracts ex post: how car manufacturers manage car dealers. Review of Law and Economics, 2005, 150-173.

Bajari, P. and Tadelis, S., 2001. Incentives versus transaction costs: a theory of procurement contracts. The Rand Journal of Economics, 32(3), 387-407.

Baker, G., Gibbons, R. and Murphy, K., 2005. Contracting for control (preliminary and incomplete version). 
Battigalli, P., and Maggi, G., 2002. Rigidity, discretion and the costs of writing contracts. The American Economic Review, 92(4), 798-817.

Bogetoft, P. and Olesen, H. 2002. Ten rules of thumb in contract design: lessons form kanish agriculture. European Review of Agricultural Economics, 29(2), 185-204.

Carriquiry, M. and Babcock, B.A., 2004. Can spot and contract markets co-exist in agriculture?. Working Paper 02-Wp 311. Iowa: Iowa State University.

Cook, M., and Chaddad, F., 2000. Agro-industrialization of the global agrifood economy: bridging developing economics and agribusiness research, Agricultural Economics, 23, 200-218.

Crémer, J., Garicano, L. and Prat, A., 2004. Codes in organizations. CEPR Discussion Paper no. 4205, London, Centre for Economic Policy Research. http://www.cepr.org/pubs/dps/DP4205.asp.

Eisenhardt, KM., 1989. Building theories from case study research. Academy of Management Review, 14(4), 532-550.

Elfenbein, DW. and Lerner, J., 2003. Ownership and control rights in Internet portal alliances. RAND Journal of Economics, 34(2), 356-369.

ERS/USDA, 2006. Agricultural contracting update: contracts in 2003. Economic Information Bulletin Number 9, Washington: ERS/USDA.

ERS/USDA, 2003. Agricultural Economic Report, 828(1):23-56, Washington: ERS/USDA.

Glover, D. and Kusterere, K., 1990. Small farmers, big business: contract farming and rural development. New York: ST. Martin's press.

Glover, D., 1984. Contract farming and smallholder outgrow schemes in lessdeveloped countries. World Development, 12(11/12), 1143-115.

Goldsmith, A. 1985. The private sector and rural development: can agribusiness help the small farmer, World Development, 13(10/11), 1125-1138.

Goodhue, R., 2000. Broiler production contracts as a multi-agent problem: common risk, incentives and heterogeneity. American Journal of Agricultural Economics, 81, 606- 622.

Goodhue, R., 1999. Input control in agricultural production contracts, American Journal of Agricultural Economics. 81, 616-620.

Goodhue, R., 1997. Production control and production contracts: why do integrators control inputs? Presented at Western Agricultural Economics Association 1997 Annual meeting, Neno/Sparks, Nevada.

Grossman, S. and Hart, O., 1986. The costs and benefits of ownership: a theory of vertical and lateral integration. Journal of Political Economy, 94(4), 691-719.

Hansmann, H., 1996. The Ownership of Enterprise. Cambridge, MA: The Belknap Press.

Hart, O. and Moore, J., 1990. Property rights and the nature of the firm. The Journal of Political Economy, 98 (6), 1119-1158.

Hennessy, D., 1996. Information asymmetry as a reason for food industry vertical integration. American Journal of Agricultural Economics, 78, 1034-1043.

Hueth, B. and Ligon, E., Producer prick risk and quality measurement. American Journal of Agricultural Economics, 81, 512-524.

Hueth, B., Ligon, E., Wolf, S. and Wu, S., 1999. Incentive instruments in fruit and vegetable contracts: input control, monitoring, measuring and price risk. Review of Agricultural Economics, 21, 374-389.

$\mathrm{Hu}, \mathrm{Y} .2007$. Essays on the governance of agricultural products: cooperatives and contract farming. Thesis (PhD). Erasmus University Rotterdam. http://hdl.handle.net/1765/10535 
Joskow, P. 1988. Asset Specificity and the Structure of Vertical Relationships: Empirical Evidence. Journal of law, Economics, and Organization, 4, 95-117.

Kwon, I. W. and Suh, T., 2004. Factors affecting the level of trust and commitment in supply chain relationship, Journal of Supply Chain Management, 40(2), 4-14.

Lerner, J. and Merges, R., 1998. The control of technology alliances: an empirical analysis of the biotechnology industry. Journal of Industrial Economics, 46, 126156.

Little, D. P. and Watts, M., eds. 1994. Live under contract: contract farming and agrarian transformation in Sub-Saharan Africa. Madison, Wisconsin: the university of Wisconsin Press.

MacDonald, J., 2004. Organizational Economic in agriculture policy analysis. American Journal of Agricultural Economics, 86(8), 44-749.

Menard, C., 1996. On clusters, hybrids and other strange forms: the case of the french poultry industry. Journal of Institutional and Theoretical Economics, 152, 154183.

Reimer, J., 2006. Vertical Integration in the pork industry. American Journal of Agricultural Economics, 88(1), 234-248.

Simester, D., and Wernerfelt, B., 2005. Determinants of Asset ownership: a study of the carpentry trade. The Review of Economics and Statistics, 87(1), 50-58.

Vukina, T. and Leegomonchai, P., 2006. Oligopsony power, asset specificity and hold-Up: evidence from the broiler industry. American Journal of Agricultural Economics, 88 (3), 589-605.

Vukina, T., 2006. The relationship between contracting and livestock waste pollute. Review of Agricultural Economics, 25(1), 66-88.

Warning, M. 2002. The social performance and distributional consequence of contract farming: an equilibrium analysis of the Arachide De Bouche Program in Senegal. World Development, 30(2), 255-263.

Wiliams, S. and Karen, R., 1985. Agribusiness and the Small-scale Farmer: a dynamic partnership for development. Boulder: Westview Press.

Williamson, O. 1983. Credible Commitments: Using Hostages to Support Exchange. American Economic Review, 73(4), 519-540.

Yin, R. 2003. Case Study Research: design and methods. Thousand Oaks, London and New Delhi: Sage Publications. 


\section{Publications in the ERIM Report Series Research* in Management}

\section{ERIM Research Program: "Organizing for Performance"}

2007

Leadership Behaviour and Upward Feedback: Findings From a Longitudinal Intervention

Dirk van Dierendonck, Clare Haynes, Carol Borrill and Chris Stride

ERS-2007-003-ORG

http://hdl.handle.net/1765/8579

The Clean Development Mechanism: Institutionalizing New Power Relations

Bettina B.F. Wittneben

ERS-2007-004-ORG

http://hdl.handle.net/1765/8582

How Today's Consumers Perceive Tomorrow's Smart Products

Serge A. Rijsdijk and Erik Jan Hultink

ERS-2007-005-ORG

http://hdl.handle.net/1765/8984

Product Intelligence: Its Conceptualization, Measurement and Impact on Consumer Satisfaction

Serge A. Rijsdijk, Erik Jan Hultink and Adamantios Diamantopoulos

ERS-2007-006-ORG

http://hdl.handle.net/1765/8580

Testing the Strength of the Iron Cage: A Meta-Analysis of Neo-Institutional Theory

Pursey P.M.A.R. Heugens and Michel Lander

ERS-2007-007-ORG

http://hdl.handle.net/1765/8581

Export Orientation among New Ventures and Economic Growth

S. Jolanda A. Hessels and André van Stel

ERS-2007-008-ORG

http://hdl.handle.net/1765/8583

Allocation and Productivity of Time in New Ventures of Female and Male Entrepreneurs

Ingrid Verheul, Martin Carree and Roy Thurik

ERS-2007-009-ORG

http://hdl.handle.net/1765/8989

Cooperating if one's Goals are Collective-Based: Social Identification Effects in Social Dilemmas as a Function of Goal-Transformation David De Cremer, Daan van Knippenberg, Eric van Dijk and Esther van Leeuwen

ERS-2007-010-ORG

http://hdl.handle.net/1765/9041

Unfit to Learn? How Long View Organizations Adapt to Environmental Jolts

Pursey P. M. A. R. Heugens and Stelios C. Zyglidopoulos

ERS-2007-014-ORG

http://hdl.handle.net/1765/9404

Going, Going, Gone. Innovation and Exit in Manufacturing Firms

Elena Cefis and Orietta Marsili

ERS-2007-015-ORG

http://hdl.handle.net/1765/9732 
High in the Hierarchy: How Vertical Location and Judgments of Leaders' Power are Interrelated

Steffen R. Giessner and Thomas W. Schubert

ERS-2007-021-ORG

http://hdl.handle.net/1765/9727

Contracts to Communities: a Processual Model of Organizational Virtue

Pursey P.M.A.R. Heugens, Muel Kaptein and J. van Oosterhout

ERS-2007-023-ORG

http://hdl.handle.net/1765/9728

Why Are Some Entrepreneurs More Innovative Than Others?

Philipp Koellinger

ERS-2007-024-ORG

http://hdl.handle.net/1765/9730

Stimulating Strategically Aligned Behaviour Among Employees

Cees B. M. van Riel, Guido Berens and Majorie Dijkstra

ERS-2007-029-ORG

http://hdl.handle.net/1765/10067

The Effectiveness of Business Codes: A Critical Examination of Existing Studies and the Development of an Integrated Research Model

Muel Kaptein and Mark Schwartz

ERS-2007-030-ORG

http://hdl.handle.net/1765/10150

Knowledge Spillovers and Entrepreneurs' Export Orientation

Dirk De Clercq, Jolanda Hessels and André van Stel

ERS-2007-038-ORG

http://hdl.handle.net/1765/10178

Silicon Valley in the Polder? Entrepreneurial Dynamics, Virtuous Clusters and Vicious Firms in the Netherlands and Flanders Willem Hulsink, Harry Bouwman and Tom Elfring

ERS-2007-048-ORG

http://hdl.handle.net/1765/10459

An Incomplete Contracting Model of Governance Structure Variety in Franchising

George Hendrikse and Tao Jiang

ERS-2007-049-ORG

http://hdl.handle.net/1765/10462

On the Evolution of Product Portfolio Coherence of Cooperatives versus Corporations: An Agent-Based Analysis of the Single Origin Constraint

George Hendrikse and Ruud Smit

ERS-2007-055-ORG

http://hdl.handle.net/1765/10505

Greenfield or Acquisition Entry: A Review of the Empirical Foreign Establishment Mode Literature

Arjen H.L. Slangen and Jean-François Hennart

ERS-2007-059-ORG

http://hdl.handle.net/1765/10539

Do Multinationals Really Prefer to Enter Culturally-Distant Countries Through Greenfields Rather than Through Acquisitions?

The Role of Parent Experience and Subsidiary Autonomy

Arjen H.L. Slangen and Jean-François Hennart

ERS-2007-060-ORG

http://hdl.handle.net/1765/10538 
The Financial Centres of Shanghai and Hong Kong: Competition or Complementarity?

Bas Karreman and Bert van der Knaap

ERS-2007-062-ORG

http://hdl.handle.net/1765/10516

Peer Influence in Network Markets: An Empirical Investigation

Jörn H. Block and Philipp Köllinger

ERS-2007-063-ORG

http://hdl.handle.net/1765/10540

Clustering in ICT: From Route 128 to Silicon Valley, from DEC to Google, from Hardware to Content Wim Hulsink, Dick Manuel and Harry Bouwman ERS-2007-064-ORG

http://hdl.handle.net/1765/10617

Leader Affective Displays and Attributions of Charisma: The Role of Arousal

Frederic Damen, Daan van Knippenberg and Barbara van Knippenberg

ERS-2007-067-ORG

http://hdl.handle.net/1765/10621

Unity through Diversity: Value-in-Diversity Beliefs, Work Group Diversity, and Group Identification

Daan van Knippenberg, S. Alexander Haslam and Michael J. Platow

ERS-2007-068-ORG

http://hdl.handle.net/1765/10620

Entrepreneurial Diversity and Economic Growth

Ingrid Verheul and André van Stel

ERS-2007-070-ORG

http://hdl.handle.net/1765/10619

Commitment or Control? Human Resource Management Practices in Female and Male-Led Businesses Ingrid Verheul

ERS-2007-071-ORG

http://hdl.handle.net/1765/10618

Allocation of Decision Rights in Fruit and Vegetable Contracts in China

Yamei Hu and George Hendrikse

ERS-2007-077-ORG

The Role of Transformational Leadership in Enhancing Team Reflexivity

Michaéla C. Schippers, Deanne N. Den Hartog, Paul L. Koopman and Daan van Knippenberg

ERS-2007-080-ORG

* A complete overview of the ERIM Report Series Research in Management: https://ep.eur.n//handle/1765/1

ERIM Research Programs:

LIS Business Processes, Logistics and Information Systems

ORG Organizing for Performance

MKT Marketing

F\&A Finance and Accounting

STR Strategy and Entrepreneurship 